\title{
Investor Protection, Stock Liquidity, and Capital Structure
}

\author{
Chuong Hong Pham ${ }^{1}$, Hoang Duc Le ${ }^{1}$, Hung Quoc Dang ${ }^{1} \&$ Uyen Tu Bui ${ }^{1}$ \\ ${ }^{1}$ National Economics University, Hanoi, Vietnam \\ Correspondence: Chuong Hong Pham, National Economics University, Hanoi, Vietnam. E-mail: \\ chuongph@neu.edu.vn
}

Received: April 19, 2020

Accepted: May 29, 2020

Online Published: July 7, 2020

doi:10.5430/ijfr.v11n4p357

URL: https://doi.org/10.5430/ijfr.v11n4p357

\begin{abstract}
This paper investigates empirically the impact of stock liquidity and investor protection on corporate capital structure. We predict that stock liquidity has a significantly negative impact on firm leverage and this negative impact is stronger in a country where the investor protection is strong. The sample consists of 2,203 firms listed in the UK, Germany, France, and Italy over the period from 2009 to 2018. Using a firm fixed effects model, we find evidence supporting our prediction. Our results are robust when we use a random effects model model, or when we employ an alternative measure of investor protection. Additionally, we find that an exogenous event that reduced the investor protection could dampen the negative impact of stock liquidity on firm leverage. Our paper suggests that future studies should consider the effects of factors related to the level of investor protection when investigating the relationship between stock liquidity and firm characteristics, such as firms' default risk.
\end{abstract}

Keywords: investor protection, stock liquidity, capital structure

\section{Introduction}

In this paper, we investigate the impact of investor protection on the relationship between stock liquidity and firm leverage. Prior studies have examined the relationship between investor protection and stock liquidity (e.g., Brockman and Chung, 2003; and Chung, 2006), the relationship between investor protection and firm leverage (e.g., Acharya et al, 2011; and Cho et al., 2014), and the relationship between stock liquidity and firm leverage (e.g., Lipson and Mortal, 2009). However, these three lines of studies have been investigated separately. To the best of our knowledge, no research has yet studied how investor protection affects the way stock liquidity interacts with firm leverage. As a result, the purpose of our paper is to fill this gap.

According to the trade-off theory of Modigliani and Miller (1958) and the pecking-order theory of Myer and Majluf (1984), there is a negative relationship between stock liquidity and firm leverage. The former theory argues that firms will use equity financing if the net cost of equity is lower than the net cost of debt. Since firms with more liquid stock have lower flotation costs for equity issuance, these firms are expected to have a low level of debt ratio in their capital structure. The latter theory argues that firms prefer to issue debt to equity when they need to raise external capital due to adverse selection costs. As a result, if the adverse selection costs can be reflected in trading costs of a firm's stock, a firm with low liquidity (e.g., high adverse selection costs) can have a high level of leverage. A few empirical studies find evidence supporting this prediction (e.g., Lipson and Mortal, 2009).

The findings on investor protection - stock liquidity relationship suggest a positive impact of investor protection on stock liquidity (e.g., Brockman and Chung, 2003; and Chung, 2006). In a country where the investor protection environment is strong, the information asymmetric problem between market participants may be mitigated. This can lead to a reduction in trading costs of a stock. Consequently, the stock liquidity can be enhanced.

It is arguable that strong investor protection can lead to a reduction in firm leverage. For example, the agency costs theory of Jensen and Meckling (1976) and Jensen (1986) suggests that debt instruments can mitigate the agency costs between minority shareholders and managers. This implies that if the agency costs are high (e.g., in countries where the protection of minority shareholders is weak), firms should employ a high level of debt ratio to reduce the high agency costs. In other words, the agency costs theory predicts a negative relationship between investor protection, which is measured by minority shareholder protection, and the firm leverage. Investor protection that protects creditors or debt-holders is another example. Cho et al. (2014) mention that in a country where the creditor rights protection is strong, managers of firms can lose the control of the firms more easily than in a country where the 
creditor rights protection is weak. As a result, firms in strong creditor rights countries tend to engage in risk-reducing activities, such as reducing leverage. Rajan and Zingales (1995), Acharya et al. (2011), and Vig (2013) find results that are consistent with this prediction.

Overall, companies in strong investor protection countries tend to use less debt. Consequently, in these countries, we predict that a small increase in the stock liquidity may lead to a large reduction in firm leverage. In contrast, companies in weak investor protection countries tend to use more debt. As a result, in these countries, we expect that a large increase in stock liquidity can only lead to a small decrease in firm leverage. In other words, we predict that the negative impact of stock liquidity on firm leverage may be stronger in strong investor protection countries than in weak investor protection countries.

Our paper uses a large sample consisting of 2,203 non-financial companies with 17,120 firm-year observations from 4 European countries for the period from 2009 to 2018. The 4 European countries are the UK, France, Germany, and Italy. These four countries have a homogenous level of economic development but have differences in the level of investor protection. Previous studies have also focused on these countries when investigating the capital structure of European countries (e.g., Rajan and Zingales, 1995; and Wanzenried, 2006).

We start our paper by revisiting the relationship between stock liquidity and firm leverage. Both the trade-off hypothesis and the pecking-order theory predict a negative relationship between stock liquidity and firm leverage. Using a firm fixed regression analysis, in which firm leverage is the dependent variable and stock liquidity is the independent variable, our results confirm this prediction. Then we interact the investor protection variable with the stock liquidity variable to examine how investor protection can affect the stock liquidity - firm leverage relation. Our results show that the negative impact of stock liquidity on firm leverage is stronger in strong investor protection countries than in weak investor protection countries. For example, in countries that have a strong protection of minority shareholders, the negative impact of stock liquidity can be 55\% stronger than one in countries that have a weak protection of minority shareholders. Similarly, in strong creditor rights countries, the negative impact of stock liquidity can be $175 \%$ stronger than one in weak creditor rights countries. Our results are robust when we employ a random effects model, or when we use an alternative measure of investor protection. Moreover, we can identify an exogenous event that reduced the investor protection in our sample. We find that the negative impact of stock liquidity on firm leverage is dampened for those companies affected by this event.

This paper contributes to the extant literature on investor protection, stock liquidity, and firm leverage. Prior studies show that strong protection of investor rights can increase stock liquidity (e.g., Brockman and Chung, 2003; and Chung, 2006) and decrease firm leverage (e.g., Acharya et al., 2011; and Cho et al., 2014). We believe we are one of the first studies to show that investor protection can also affect the relationship between stock liquidity and firm leverage. Specifically, the negative relation between stock liquidity and firm leverage is stronger in countries where the level of investor protection is higher than in countries where the level of investor protection is low.

The remainder of our paper is presented as follows. Section 2 provides a literature review relevant to our studies. Section 3 describes the data, variable construction, and methodology employed in our paper. In Section 4, we present our analysis with the empirical results. Section 5 concludes.

\section{Literature Review and Hypothesis Development}

\subsection{Stock Liquidity and Leverage}

The relationship between stock liquidity and firm leverage is of interest to a larger number of scholars in the world. The two traditional capital structure theories, which are the trade-off theory and the pecking-order theory, predict a negative relationship between stock liquidity and firm leverage. The trade-off theory, proposed by Modigliani and Miller (1958), suggests that the optimal capital structure of a firm is determined by the net cost of equity against the net cost of debt when the firm wants to raise capital. According to the trade-off theory, factors that decrease the net cost of equity could lead to an increase in the level of equity in the firm's capital structure. The model of Amihud and Mendelson (1986) proves that the required rate of return for equity investment can be an increasing and concave function of the stock spread. Given that the stock spread is negatively associated with the stock liquidity, the model of Amihud and Mendelson (1986) suggests that stock liquidity and cost of equity have a negative relationship. A number of previous studies also find evidence showing that stock liquidity exert a negative effect on the stock required rate of return (e.g., Chordia et al., 2001; and Marshall and Young, 2003)

In contrast, stock illiquidity is argued to have a positive impact on the cost of equity. Brennan et al. (1998) and Brennan and Subrahmanam (1996) find that equity holders require a higher return to compensate for the risk of the stock illiquidity. Acharya and Pedersen (2005) and Pastor and Stambaugh (2003) also point out that there are 
liquidity risk premiums that are usually high for illiquid stocks. Additionally, Stoll and Whaley (1983) show that compared to large firms, small firms are expected to have a higher rate of return because the stocks of the small firms are more illiquid. Martinez et al. (2005) empirically find a positive relationship between stock returns and stock illiquidity. The general conclusion of these studies is that the net cost of equity for firms with illiquid stocks is more expensive, making equity financing less attractive than debt financing. Consequently, these firms are more likely to use debt financing when raising capital.

The pecking-order theory of Myers and Majluf (1984) suggests that because there is asymmetric information between firms' management and the potential investors, firms prefer to use internal equity over debt, and prefer to use debt over external equity when they need to raise capital. The stock trading costs can reflect the asymmetric information if the asymmetric information between the firms' management and the market is correlated with the asymmetric information between the market participants. Under this assumption, a high level of asymmetric information is associated with a high level of stock trading costs and a low level of stock liquidity. As a result, a firm with less stock liquidity (e.g., more asymmetric information) is more likely to issue debt over equity. This implies a negative relationship between stock liquidity and firm leverage.

A number of prior studies investigate the relationship between stock liquidity and firm leverage and offer empirical evidence supporting the theoretical prediction of the trade-off theory and the pecking-order theory. For instance, Frieder and Martell (2006) find an inverse relationship between stock liquidity and firm leverage for all firms listed on the New York Stock Exchange (NYSE). Using similar US data, Lipson and Mortal (2009) also show that firms with more stock liquidity have lower leverage. Additionally, they document that firms prefer equity to debt when raising capital when the firms have a high level of stock liquidity. Udomsirikul et al. (2011) demonstrate that there is a negative relationship between stock liquidity and firm leverage for Thailand listed firms. Nadarajah et al. (2018), using a panel of firms listed on Australian Securities Exchange (ASX), find a negative stock liquidity - leverage relation. Overall, based on the theoretical prediction and on the empirical evidence of the negative relationship between stock liquidity and firm leverage, we develop our first hypothesis as follows:

Hypothesis 1: Firms with higher stock liquidity are associated with a lower level of leverage.

\subsection{Investor Protection, Stock Liquidity, and Capital Structure}

Recent studies have investigated firms' stock liquidity in the international context. For example, Lang et al. (2011) mention that firms with greater stock liquidity have a higher level of transparency. Furthermore, they document that this relationship is stronger for firms in countries with poor investor protection. Charoenwong et al. (2014) show that firms possessing greater asset liquidity are associated with higher stock liquidity and this relationship is more pronounced in countries with poor accounting standards. Dang et al. (2017) report that an increase in institutional ownership can exert a positive impact on stock liquidity. Moreover, they mention that this impact is stronger in countries with poor institutional characteristics. Huang et al. (2020) examine the relationship between investor protection and the value impact of stock liquidity and find that the value impact of stock liquidity in countries with strong investor protection is stronger than that in countries with weak investor protection. Although these studies cover a relatively large stream of corporate finance literature on stock liquidity in the international context, the number of studies investigating how the difference in countries' investor protection impacts the way stock liquidity interacts with firm leverage is scarce.

Investor protection, which affects both stock liquidity and firm leverage, can affect the relationship between stock liquidity and firm leverage. With respect to the impacts of investor protection on stock liquidity, an increase in investor protection can increase stock liquidity. A good investor protection environment, which can decrease the probability of trading against informed traders, can reduce the trading costs related to information asymmetry. As a result, the liquidity supplier can offer narrower bid-ask spreads and liquidity demander can enjoy the reduction in the bid-ask spreads. A good investor protection, therefore, can increase stock liquidity. Brockman and Chung (2003) and Chung (2006) find empirical evidence showing that strong investor protection can lead to an increase in stock liquidity.

Regarding the effects of investor protection, which focuses on minority shareholders and debt-holders, on firm leverage, it is argued that in countries where investors are more protected against the expropriation by the corporate insiders, firms are less likely to use debt in their capital structure. For minority shareholders, the protection is necessary to reduce the agency costs between them and the managers. The theory of agency costs between shareholders and managers predicts that debt instruments can reduce the agency costs (Jensen and Meckling, 1976; and Jensen, 1986). In a country where the protection of minority shareholders is weak, the agency costs between them and the managers are high, and therefore firms should increase debt ratio to attenuate the high agency costs. 
This suggests a negative relation between the degree of minority shareholders protection and firm leverage.

For debt-holders, in countries where the protection of debt-holders is strong, it is difficult for firms' managers to expropriate their debt-holders. In these countries, firms are less likely to engage in risk-taking activities such as increasing leverage because these activities can increase the firms' likelihood of default. If the firms go bankrupt, the firms' managers would lose the control of the firms more easily than in countries where the protection of debt-holders is weak. This implies that the level of debt-holders protection has a negative relationship with the firm leverage. A few empirical studies find evidence supporting this prediction (e.g, Rajan and Zingales, 1995; Acharya et al., 2011; Vig, 2013; and Cho et al., 2014).

In conclusion, prior studies suggest that companies in strong investor protection countries tend to use less debt because the companies in these countries have less room to expropriate the outside investors than those in countries with weak investor protection. Additionally, adverse selection problems are weaker in a strong investor protection country. In a strong investor protection country, if the adverse selection problems in a firm increase a little, this increase hardly changes the firm's stock liquidity because the investors are aware that they are protected from the managers' expropriation and thereby they do not need to change their trading or investing behaviour. However, they will adjust their trading or investing behaviour if they predict that the adverse selection problems in the firm increase remarkably. Thus, a reduction, even small, in a firm's stock liquidity in strong investor protection countries reflects a substantial increase in adverse selection costs, which implies that the firms will have to use more debt financing if they need to raise external finance. This suggests that the negative impact of stock liquidity on the firm leverage is stronger in countries with strong investor protection than in countries with weak investor protection. As a result, we develop our second hypothesis as follows:

Hypothesis 2: The negative impact of stock liquidity on firm leverage is stronger in countries with strong investor protection than in countries with weak investor protection.

\section{Data, Variable Construction, and Methodology}

\subsection{Data}

Our sample consists of all the listed firms in the UK, France, Germany, and Italy for the period from 2009 to 2018. We source these firms from Datastream database. The reason to select those four European countries follows Rajan and Zingales (1995) and Wanzenried (2006). Although the economic development of these countries is fairly homogeneous, they are also characterized by fairly different investor protection environments. This helps us understand how the between-country differences in investor protection arrangements can affect the relationship between stock liquidity and firm leverage. We exclude financial companies, such as bank or investment and insurance companies, from our sample since these companies are subject to specific rules and regulations and therefore have their own distinctive characteristics in the capital structure.

For the firms in our sample, we collect the stock trading data and the financial data from Datastream database. We require that these firms need to have available financial information to calculate the variables in our paper. Our final sample is an unbalanced panel consisting of 2,203 companies with 17,120 firm-year observations. We collect the data for investor protection from the previous studies. In our paper, we use an anti-director rights index and a creditor rights index as the proxies for investor protection. We collect the data for the anti-director rights index and creditor rights index from Djankov et al. (2008) and Djankov et al. (2007), respectively.

\subsection{Variable Construction}

\subsubsection{Measures of Capital Structure}

Previous studies use both book and market values to compute a company's leverage. The book value of leverage is measured as the ratio of the total debt to the book value of total assets, whereas the market value of leverage is calculated as the ratio of the total debt over the market value of total assets, where the market value of total assets is computed as the sum of total debt plus the market value of equity. Given that the market value reflects the market reaction of investors and other related information, such as agency costs, better than the book value, we will employ the market value of leverage in our paper (LEVERAGE).

\subsubsection{Measures of Stock Liquidity}

We follow the previous studies in stock liquidity and employ two common measurements for stock liquidity that can capture the price impact and the trading costs of a stock. The first variable that captures the price impact of a stock is Amihud's (2002) illiquidity ratio (AMIHUD). The formula to calculate AMIHUD is as follows: 


$$
A M I H U D_{i d}=10^{6} \cdot \frac{R_{i d}}{V_{i d}}
$$

where Rid and Vid are the daily stock return and the daily dollar trading volume of stock i in day d, respectively. We calculate the annual AMIHUD by taking the average of daily AMIHUD over trading days in each year. The price impact of a stock represents the adverse selection cost of trades. A higher AMIHUD indicates a more illiquid (less liquid) stock. Since the AMIHUD is highly skewed to the right, we take the natural logarithm of one plus the annual AMIHUD to reduce the right skewness of this variable.

The second variable that captures the trading costs of a stock is the quoted spread (QUOTED_SPREAD). The formula to calculate QUOTED_SPREAD is as follows:

$$
\text { QUOTED_SPREAD } \left.D_{i d}=2 \cdot \frac{\left(A S K_{i d}\right.}{\left(A S K_{i d}+B I D_{i d}\right)}\right)
$$

where ASKid and BIDid are the asking and bid price of stock $\mathrm{i}$ in day d, respectively. We compute the annual QUOTED_SPREAD by taking the average of daily QUOTED_SPREAD over trading days in each year. We exclude firm-year observations that have a negative value of the quoted spread. The bid-ask spread represents the cost of trading that is borne by the liquidity demanders when they trade with the liquidity suppliers at the prices quoted by the liquidity suppliers. The bid-ask spread includes the inventory and order processing cost, the economic rent, and the adverse selection cost, which is equal to one in the price impact of the stock. A higher QUOTED_SPREAD indicates a more illiquid (less liquid) stock.

\subsubsection{Measure of Investor Protection}

We use the two following variables to proxy for investor protection. The first variable is anti-director rights index (ANTI_DIRECTOR_INDEX), which is gathered from Djankov et al. (2008). In essence, this index measures the protection for minority shareholders against the appropriation of the directors. The anti-director rights index will take the value from 0 to 6 . A higher anti-director rights index indicates a stronger protection for the minority shareholders.

The second variable proxied for investor protection in our paper is creditor rights index (CREDITOR_RIGHTS_INDEX), which is sourced from Djankov et al. (2007). This index measures the protection for creditors against defaulting debtors. The creditor rights index ranges from 0 to 4 , with a higher score being associated with a stronger protection for creditors.

\subsubsection{Control Variables}

We follow the previous empirical studies to select control variables in our multivariate regression analysis (e.g., Wanzenried, 2006; Acedo-Ramirez and Ruiz-Cabestre, 2014; Cho et al., 2014). The first control variable is firm size (FIRM_SIZE), measured by the natural logarithm of total sales. The second control variable captures the effects of fixed assets (FIXED_ASSET). We measure FIXED_ASSET by the ratio of the value of property, plants, and equipment over the total assets. The third control variable is firm profitability (PROFITABILITY). In our paper, we use the ratio of earning before interest and taxes over the total assets as the measure for the firm profitability. The next variable controls firm growth opportunities (MARKET_TO_BOOK), computed as the ratio of the market price per share over the book value per share. The final control variable is the tax shield (TAX_SHIELD). We approximate the firm tax shield by the ratio of the income taxes over total assets.

\subsection{Methodology}

We investigate the impact of investor protection on the relationship between stock liquidity and firm leverage by employing a firm fixed effects model to regress the following equation:

LEVERAGE $_{\mathrm{it}}=\alpha_{0}+\beta_{1}$ STOCK_LIQUIDITY $_{\mathrm{it}}+\beta_{2}$ STOCK_LIQUIDITY $_{\mathrm{it}} *$ INVESTOR_PROTECTION $_{\mathrm{i}}+$ $\gamma \mathrm{CONTROL}_{\text {it }}+\varepsilon_{\text {it }}$

where $\mathrm{i}$ indexes firm $\mathrm{i}$ and $\mathrm{t}$ indexes year $\mathrm{t}$. The dependent variable is firm leverage. The first independent variable is STOCK_LIQUIDITY, which is measured by AMIHUD or QUOTED_SPREAD. The second independent variable is INVESTOR_PROTECTION, which is proxied by ANTI_DIRECTOR_INDEX or CREDITOR_RIGHTS_INDEX. The INVESTOR_PROTECTION variable for company $\mathrm{i}$ will be the investor protection index of the country where the company $i$ has its headquarter. We do not include this variable in Equation 3 because the value of this variable does not vary overtime for each company. However, we add an interaction term between STOCK_LIQUIDITY and INVESTOR_PROTECTION variables to examine the impact of investor protection on the relationship between stock liquidity and firm leverage. CONTROL is a set of control variables mentioned in Section 3.2.4. Finally, $\varepsilon$ is the 
error term of the model.

In our paper, we use a firm fixed effect model to estimate Equation 3. This is because the firm fixed effects model can mitigate the endogeneity problems caused by the omitted time-invariant variables. In a robustness test, we will employ a random effects model to estimate Equation 3. Our coefficient of interest is the coefficient estimated on the interaction term between stock liquidity variables and investor protection variables, which is predicted to be positive. To capture the different effects of each year on the capital structure, we include the year dummy variables in Equation 3. The continuous variables will be winsorized at the 1st and 99th percentile to mitigate the impact of the outliers. The estimated standard errors are adjusted for heteroskedasticity and clustered at the firm level.

\section{Empirical Results}

\subsection{Summary Statistics}

Table 1 reports summary statistics for all variables used in Equation 3.

Table 1. Summary statistics

\begin{tabular}{|c|c|c|c|c|c|c|c|c|}
\hline \multicolumn{9}{|c|}{ Panel A: Summary statistics by country } \\
\hline \multirow[t]{2}{*}{ Variable } & \multicolumn{2}{|c|}{ United Kingdom } & \multicolumn{2}{|c|}{ Germany } & \multicolumn{2}{|l|}{ France } & \multicolumn{2}{|l|}{ Italy } \\
\hline & $\mathrm{N}$ & Mean & $\mathrm{N}$ & Mean & $\mathrm{N}$ & Mean & $\mathrm{N}$ & Mean \\
\hline LEVERAGE & 7,100 & 0.171 & 3,679 & 0.218 & 4,685 & 0.267 & 1,656 & 0.397 \\
\hline ANTI_DIRECTOR_INDEX & 7,100 & 5.000 & 3,679 & 3.500 & 4,685 & 3.500 & 1,656 & 2.000 \\
\hline CREDITOR_RIGHTSS_INDEX & 7,100 & 4.000 & 3,679 & 3.000 & 4,685 & 0.000 & 1,656 & 2.000 \\
\hline AMIHUD -- & 7,083 & 0.666 & 3,679 & 3.635 & 4,593 & 0.991 & 1,646 & 1.960 \\
\hline QUOTED_SPREAD & 7,090 & 0.053 & 3,668 & 0.034 & 4,678 & 0.058 & 1,655 & 0.018 \\
\hline FIRM_SIZE & 7,100 & 11.599 & 3,675 & 12.373 & 4,685 & 12.107 & 1,656 & 12.765 \\
\hline FIXED_ASSETS & 7,100 & 0.226 & 3,679 & 0.210 & 4,685 & 0.172 & 1,656 & 0.224 \\
\hline PROFITABILITY & 7,100 & -0.031 & 3,679 & 0.020 & 4,685 & 0.002 & 1,656 & 0.029 \\
\hline MARKET_TO_BOOK & 7,100 & 2.825 & 3,679 & 2.508 & 4,685 & 2.029 & 1,656 & 2.098 \\
\hline TAX_SHIELD & 7,100 & 0.008 & 3,679 & 0.015 & 4,685 & 0.010 & 1,656 & 0.015 \\
\hline & nel B: S & mmary & tistics & r the who & sample & & & \\
\hline Variable & $\mathrm{N}$ & & & Median & Std. Dev & 5 th & & 95th \\
\hline LEVERAGE & 17,1 & & & 0.169 & 0.223 & 0.00 & & 0.687 \\
\hline ANTI_DIRECTOR_INDEX & 17,1 & & & 3.500 & 0.961 & 2.00 & & 5.000 \\
\hline CREDITOR_RIGHTSS_INDEX & 17,1 & & & 3.000 & 1.650 & 0.00 & & 4.000 \\
\hline AMIHUD - & 16,9 & & & 0.710 & 1.782 & $>0.0$ & & 5.120 \\
\hline QUOTED_SPREAD & 17,0 & & 47 & 0.020 & 0.093 & 0.00 & & 0.180 \\
\hline FIRM_SIZE & 17,1 & & 017 & 12.001 & 2.729 & 7.51 & & 16.704 \\
\hline FIXED_ASSETS & 17,1 & & 08 & 0.135 & 0.212 & 0.00 & & 0.671 \\
\hline PROFITABILITY & 17,1 & & 005 & 0.051 & 0.251 & -0.4 & & 0.202 \\
\hline MARKET_TO_BOOK & 17,1 & & 69 & 1.640 & 3.912 & 0.28 & & 8.12 \\
\hline TAX_SHIELD & 17,1 & & & 0.010 & 0.028 & -0.0 & & 0.053 \\
\hline
\end{tabular}

In Panel A, we summarize these variables by country. With regard to firm leverage, the table clearly shows that German firms have the highest leverage, followed by French firms, whereas UK firms have the lowest leverage. Looking at institutional variables, the UK seems to provide the best protection to investors. Both anti-director rights and creditor rights index of the UK are the highest among the considered countries. In contrast, the lowest score for the anti-director rights and the creditor rights index belongs to Italy and France, respectively. This suggests that investor protection in France and Italy seems to be rather weak. The difference in the investor protection environment enables our study to investigate the impact of investor protection on the relationship between stock liquidity and firm leverage.

With respect to stock liquidity measures, the picture differs depending on what proxy is used to measure the stock liquidity. For the Amihud measure, UK stocks have the highest liquidity, whereas German stocks have the lowest liquidity. For the quoted spread measure, Italian firms possess the most liquid stock, while French firms possess the least liquid stock. 
In Panel B of Table 1, we report the summary statistics for the whole sample. The mean value of firm leverage is 0.229 with the standard deviation of 0.223 . Additionally, we observe that the mean of Amihud and quoted spread is 1.520 and 0.047 , respectively.

\subsection{Multivariate Results}

We begin our analysis by using a fixed effects model to estimate the relationship between stock liquidity and firm leverage for each country in our sample. The results are presented in Table 2. We report the results for the UK, Germany, France, and Italy in columns 1-2, 3-4, 5-6, and 7-8, respectively.

Table 2. Regressions of firm leverage on stock liquidity by country

\begin{tabular}{|c|c|c|c|c|c|c|c|c|}
\hline \multirow[b]{3}{*}{ VARIABLES } & \multicolumn{8}{|c|}{ Dependent variable: LEVERAGE } \\
\hline & \multicolumn{2}{|c|}{ United Kingdom } & \multicolumn{2}{|c|}{ Germany } & \multicolumn{2}{|c|}{ France } & \multicolumn{2}{|c|}{ Italy } \\
\hline & $(1)$ & (2) & (3) & (4) & $(5)$ & (6) & (7) & (8) \\
\hline AMIHUD & $\begin{array}{c}0.046^{* * * *} \\
(0.005)\end{array}$ & & $\begin{array}{c}0.036 \text { **** } \\
(0.005)\end{array}$ & & $\begin{array}{c}0.032 * * * \\
(0.006)\end{array}$ & & $\begin{array}{c}0.037 \text { **** } \\
(0.008)\end{array}$ & \\
\hline QUOTED_SPREAD & & $\begin{array}{c}0.305 * * * \\
(0.064)\end{array}$ & & $\begin{array}{c}0.470^{* *} \\
(0.227)\end{array}$ & & $\begin{array}{c}0.110^{* *} \\
(0.051)\end{array}$ & & $\begin{array}{c}0.290 \\
(0.488)\end{array}$ \\
\hline FIRM_SIZE & $\begin{array}{c}0.023^{* * * *} \\
(0.004)\end{array}$ & $\begin{array}{c}0.022 * * * \\
(0.004)\end{array}$ & $\begin{array}{c}0.030^{* * * *} \\
(0.008)\end{array}$ & $\begin{array}{c}0.023 * * * \\
(0.008)\end{array}$ & $\begin{array}{c}0.033 * * * \\
(0.008)\end{array}$ & $\begin{array}{c}0.031^{\text {**** }} \\
(0.009)\end{array}$ & $\begin{array}{c}0.060 * * * * \\
(0.014)\end{array}$ & $\begin{array}{c}0.051 * * * \\
(0.014)\end{array}$ \\
\hline FIXED_ASSETS & $\begin{array}{c}0.141^{* * * *} \\
(0.043)\end{array}$ & $\begin{array}{c}0.144 * * * \\
(0.045)\end{array}$ & $\begin{array}{c}0.242^{* * * *} \\
(0.061)\end{array}$ & $\begin{array}{c}0.237 * * * \\
(0.063)\end{array}$ & $\begin{array}{c}0.307 * * * \\
(0.077)\end{array}$ & $\begin{array}{c}0.288 * * * \\
(0.084)\end{array}$ & $\begin{array}{c}0.122 \\
(0.091)\end{array}$ & $\begin{array}{c}0.102 \\
(0.091)\end{array}$ \\
\hline PROFITABILITY & $\begin{array}{c}-0.047 * * * \\
(0.011)\end{array}$ & $\begin{array}{c}-0.054 * * * \\
(0.012)\end{array}$ & $\begin{array}{c}-0.057 * * * \\
(0.021)\end{array}$ & $\begin{array}{c}-0.063 * * * \\
(0.022)\end{array}$ & $\begin{array}{c}-0.128 * * * \\
(0.027)\end{array}$ & $\begin{array}{c}-0.118 * * * \\
(0.029)\end{array}$ & $\begin{array}{c}-0.401 * * * \\
(0.071)\end{array}$ & $\begin{array}{c}-0.403 * * * \\
(0.070)\end{array}$ \\
\hline MARKET_TO_BOOK & $\begin{array}{c}-0.003 * * * \\
(0.001)\end{array}$ & $\begin{array}{c}-0.004^{* * * *} \\
(0.001)\end{array}$ & $\begin{array}{c}-0.005^{* * * *} \\
(0.001)\end{array}$ & $\begin{array}{c}-0.005^{* * * *} \\
(0.001)\end{array}$ & $\begin{array}{c}-0.005^{* * * *} \\
(0.001)\end{array}$ & $\begin{array}{c}-0.006^{* * * *} \\
(0.001)\end{array}$ & $\begin{array}{l}-0.001 \\
(0.002)\end{array}$ & $\begin{array}{l}-0.002 \\
(0.002)\end{array}$ \\
\hline TAX_SHIELD & $\begin{array}{c}-0.653^{* * *} \\
(0.122)\end{array}$ & $\begin{array}{c}-0.666^{* * * *} \\
(0.124)\end{array}$ & $\begin{array}{c}-0.482 * * * \\
(0.144)\end{array}$ & $\begin{array}{c}-0.513^{* * * *} \\
(0.152)\end{array}$ & $\begin{array}{c}-0.584 * * * \\
(0.179)\end{array}$ & $\begin{array}{c}-0.627 * * * \\
(0.183)\end{array}$ & $\begin{array}{l}-0.332 \\
(0.379)\end{array}$ & $\begin{array}{l}-0.415 \\
(0.389)\end{array}$ \\
\hline Constant & $\begin{array}{c}-0.135 * * * \\
(0.047)\end{array}$ & $\begin{array}{c}-0.099 * * \\
(0.046)\end{array}$ & $\begin{array}{c}-0.322 * * * \\
(0.110)\end{array}$ & $\begin{array}{l}-0.114 \\
(0.103)\end{array}$ & $\begin{array}{c}-0.183^{* *} \\
(0.092)\end{array}$ & $\begin{array}{l}-0.130 \\
(0.101)\end{array}$ & $\begin{array}{c}-0.461 * * \\
(0.191)\end{array}$ & $\begin{array}{l}-0.274 \\
(0.186)\end{array}$ \\
\hline Observations & 7,083 & 7,090 & 3,668 & 3,675 & 4,593 & 4,678 & 1,646 & 1,655 \\
\hline Industry fixed effects & No & No & No & No & No & No & No & No \\
\hline Year fixed effects & Yes & Yes & Yes & Yes & Yes & Yes & Yes & Yes \\
\hline R-squared & 0.136 & 0.106 & 0.152 & 0.120 & 0.138 & 0.109 & 0.260 & 0.222 \\
\hline
\end{tabular}

Note: $* * *, * *$, and $*$ indicate statistical significance at the $1 \%, 5 \%$, and $10 \%$ level, respectively.

The results show that the coefficients on Amihud and quoted spread variables are positive and significant at at least the 5 percent level in columns from 1 to 6 . This suggests that an increase in stock liquidity of the UK firms, German firms, or French firms, whether is measured by Amihud or quoted spread, is associated with a reduction in the firm leverage. However, for Italy, only the coefficient on Amihud variable is significantly positive, whereas the coefficient on quoted spread variable, albeit positive, is insignificant. Among the UK, Germany, and France, the coefficients on stock liquidity variables of French firms are the lowest. This may imply that the negative impact of stock liquidity on the firm leverage in France is the weakest among the three countries. The result showing that the negative impact of stock liquidity on the firm leverage in France and Italy is weaker than one in the UK and Germany may be explained by the fact that the investor protection in France and Italy, measured by anti-director rights and creditor rights index, is weaker than one in the UK and Germany. This implies that the impact of stock liquidity on firm leverage is not homogeneous in different countries, confirming the necessity of examining this relationship in an international context.

In Table 3, we interact the stock liquidity variables with the investor protection variables and estimate Equation 3 using a firm fixed effects model. 
Table 3. Regressions of firm leverage on stock liquidity and investor protection

\begin{tabular}{|c|c|c|c|c|}
\hline \multirow[b]{2}{*}{ VARIABLES } & \multicolumn{4}{|c|}{ Dependent variable: LEVERAGE } \\
\hline & $(1)$ & $(2)$ & (3) & (4) \\
\hline AMIHUD & $\begin{array}{l}0.022 * * \\
(0.011)\end{array}$ & $\begin{array}{l}0.032 * * * \\
(0.005)\end{array}$ & & \\
\hline QUOTED_SPREAD & & & $\begin{array}{l}-0.129 \\
(0.214)\end{array}$ & $\begin{array}{l}0.121 * * \\
(0.052)\end{array}$ \\
\hline AMIHUD*ANTI_DIRECTOR_INDEX & $\begin{array}{l}0.004 * \\
(0.003)\end{array}$ & & & \\
\hline AMIHUD*CREDITOR_RIGHTS_INDEX & & $\begin{array}{l}0.003 \\
(0.002)\end{array}$ & & \\
\hline QUOTED_SPREAD*ANTI_DIRECTOR_INDEX & & & $\begin{array}{l}0.085^{*} \\
(0.052)\end{array}$ & \\
\hline QUOTED_SPREAD*CREDITOR_RIGHTS_INDEX & & & & $\begin{array}{l}0.053 * * * \\
(0.021)\end{array}$ \\
\hline FIRM_SIZE & $\begin{array}{l}0.031 * * * \\
(0.003)\end{array}$ & $\begin{array}{l}0.030 * * * \\
(0.003)\end{array}$ & $\begin{array}{l}0.027 * * * \\
(0.003)\end{array}$ & $\begin{array}{l}0.027 * * * \\
(0.003)\end{array}$ \\
\hline FIXED_ASSETS & $\begin{array}{l}0.182 * * * \\
(0.032)\end{array}$ & $\begin{array}{l}0.182 * * * \\
(0.032)\end{array}$ & $\begin{array}{l}0.180 * * * \\
(0.033)\end{array}$ & $\begin{array}{l}0.180 * * * \\
(0.033)\end{array}$ \\
\hline PROFITABILITY & $\begin{array}{l}-0.076 \text { *** } \\
(0.010)\end{array}$ & $\begin{array}{l}-0.077 * * * \\
(0.010)\end{array}$ & $\begin{array}{l}-0.081 * * * \\
(0.010)\end{array}$ & $\begin{array}{l}-0.080 * * * \\
(0.010)\end{array}$ \\
\hline MARKET_TO_BOOK & $\begin{array}{l}-0.004 * * * \\
(0.000)\end{array}$ & $\begin{array}{l}-0.004 * * * \\
(0.000)\end{array}$ & $\begin{array}{l}-0.004 * * * \\
(0.000)\end{array}$ & $\begin{array}{l}-0.004 * * * \\
(0.000)\end{array}$ \\
\hline TAX_SHIELD & $\begin{array}{l}-0.618 * * * \\
(0.083)\end{array}$ & $\begin{array}{l}-0.617 * * * \\
(0.083)\end{array}$ & $\begin{array}{l}-0.650 * * * \\
(0.086)\end{array}$ & $\begin{array}{l}-0.648 * * * \\
(0.086)\end{array}$ \\
\hline Constant & $\begin{array}{l}-0.208^{* * *} \\
(0.041)\end{array}$ & $\begin{array}{l}-0.209 * * * \\
(0.041)\end{array}$ & $\begin{array}{l}-0.113^{* * * *} \\
(0.041)\end{array}$ & $\begin{array}{l}-0.116^{* * * *} \\
(0.041)\end{array}$ \\
\hline Observations & 16,990 & 16,990 & 17,098 & 17,098 \\
\hline Industry fixed effects & No & No & No & No \\
\hline Year fixed effects & Yes & Yes & Yes & Yes \\
\hline R-squared & 0.136 & 0.136 & 0.104 & 0.105 \\
\hline
\end{tabular}

$* * *, * *$, and * indicate statistical significance at the $1 \%, 5 \%$, and $10 \%$ level, respectively.

The stock liquidity variables are the Amihud and the quoted spread in columns 1-2 and 3-4, respectively. The coefficients on stock liquidity variables are significantly positive in columns 1,2 , and 4 , implying a negative (positive) effect of stock liquidity (illiquidity) on firm leverage. These results support our hypothesis 1 and are in line with one of Frieder and Martell (2006), Lipson and Mortal (2009), Udomsirikuk et al. (2011), and Nadarajah et al. (2018). More importantly, the coefficients on the interaction term between the stock liquidity variables and investor protection are positive and significant in 3 out of 4 columns. Given that a high score of investor protection variables is associated with a strong investor protection, this result suggests that the negative (positive) impact of stock liquidity (illiquidity) on firm leverage is stronger in the countries with strong investor protection. This result is consistent with our hypothesis 2 . The economic impact of the investor protection on the relationship between stock liquidity and firm leverage is also significant. For example, in column 1, if the anti-director rights index increases from 2 (minimum in our sample) to 5 (maximum in our sample), the negative impact of stock liquidity on firm leverage can increase by approximately 55\%. Similarly, in column 4 , if the creditor rights index increase from 0 (minimum in our sample) to 4 (maximum in our sample), the negative impact of stock liquidity on firm leverage can increase by around $175 \%$. In unreported analysis, our sign and significance of the coefficient estimated on the interaction term between stock liquidity and investor protection variables remain mainly similar when we use a book value of leverage. 
With regard to control variables, except for the tax shield variable, the coefficients on the other control variables are generally consistent with our prediction. The coefficient on firm size is significantly positive at the 1 percent level, which is in line with the notion that larger firms have a lower probability of default and therefore can have a higher level of debt. The significantly positive coefficient on fixed assets implies that fixed assets can help the firms employ more debt in the capital structure. The coefficient estimated on firm profitability is significantly negative at the 1 percent level, which is consistent with the pecking order theory. Finally, growth firms with high market-to-book ratio are associated with a low level of leverage due to the high agency costs between shareholders and bondholders.

\subsection{Robustness Tests}

Our paper performs three sets of robustness tests to check the robustness of the results. In the first robustness test, we employ a random effects model to estimate Equation 3. By using a random effects model, we can estimate the coefficients on the investor protection variables that do not vary over time. In this model, we include the industry dummy variables to capture the effects of different industries on the firm leverage. The results estimated from a random effects model are reported in Table 4.

Table 4. Random effects model of the effect of stock liquidity and investor protection on the firm leverage

\begin{tabular}{|c|c|c|c|c|}
\hline \multirow[b]{2}{*}{ VARIABLES } & \multicolumn{4}{|c|}{ Dependent variable: LEVERAGE } \\
\hline & $(1)$ & $(2)$ & $(3)$ & $(4)$ \\
\hline AMIHUD & $\begin{array}{l}0.013 \\
(0.009)\end{array}$ & $\begin{array}{l}0.032 * * * \\
(0.004)\end{array}$ & & \\
\hline QUOTED_SPREAD & & & $\begin{array}{l}-0.138 \\
(0.185)\end{array}$ & $\begin{array}{l}0.125 * * * \\
(0.044)\end{array}$ \\
\hline ANTI_DIRECTOR_INDEX & $\begin{array}{l}-0.039 * * * \\
(0.005)\end{array}$ & & $\begin{array}{l}-0.060 * * * \\
(0.004)\end{array}$ & \\
\hline CREDITOR_RIGHTS & & $\begin{array}{l}-0.025^{* * *} \\
(0.002)\end{array}$ & & $\begin{array}{l}-0.027 * * * \\
(0.002)\end{array}$ \\
\hline AMIHUD*ANTI_DIRECTOR_INDEX & $\begin{array}{l}0.005^{*} \\
(0.002)\end{array}$ & & & \\
\hline AMIHUD*CREDITOR_RIGHTS_INDEX & & $\begin{array}{l}0.001 \\
(0.001)\end{array}$ & & \\
\hline QUOTED_SPREAD*ANTI_DIRECTOR_INDEX & & & $\begin{array}{l}0.092^{* *} \\
(0.045)\end{array}$ & \\
\hline QUOTED_SPREAD*CREDITOR_RIGHTS_INDEX & & & & $\begin{array}{l}0.057 * * * \\
(0.018)\end{array}$ \\
\hline & & (control var & bles included) & \\
\hline Observations & 16,990 & 16,990 & 17,098 & 17,098 \\
\hline Industry fixed effects & Yes & Yes & Yes & Yes \\
\hline Year fixed effects & Yes & Yes & Yes & Yes \\
\hline R-squared & 0.269 & 0.278 & 0.291 & 0.261 \\
\hline
\end{tabular}

Note: $* * *, * *$, and $*$ indicate statistical significance at the $1 \%, 5 \%$, and $10 \%$ level, respectively.

The structure of Table 4 is similar to that of Table 3. In columns 1 and 2, the stock liquidity variable is Amihud, whereas in columns 3 and 4 , the stock liquidity variable is quoted spread. Our main results estimated from the random effects model are similar to one estimated from the firm fixed effects model. The coefficients estimated on the interaction term between stock liquidity variables and investor protection variables are statistically significant in three out of four columns. Regarding the investor protection variables, we find that anti-director rights index is negatively associated with the firm leverage. The agency costs theory of Jensen and Meckling (1976) and Jensen (1986) suggests that debt can be a useful tool to reduce the agency costs between the minority shareholders and the managers, who are also the firms' directors in many companies. As a result, a possible explanation for our finding 
may be that in countries with a high anti-director rights index, firms do not need to use debt instruments to curb the agency costs. Similar to the anti-director rights index, our results show that creditor rights index also has a negative relationship with the firm leverage. This result is consistent with one in the previous studies (e.g., Rajan and Zingales, 1995; Acharya et al., 2011; Vig, 2013; and Cho et al., 2014) and can be explained because of the risk-reducing activities of firms in strong creditor rights countries.

In the second robustness test, we use a new proxy for investor protection that replaces the anti-director rights index. This new variable is the anti-self-dealing index (ANTI_SELF_DEALING), which is constructed by Djankov et al. (2008). Djankov et al. (2008) constructed the indexes for the ex ante and the ex post private control of self-dealing. The anti-self-dealing index is calculated as the average of the indexes of the ex ante and the ex post private control of self-dealing and ranges from 0 to 1 . The anti-self-dealing measures the protection for minority shareholders against the self-dealing transactions of the controlling shareholders that can harm the benefits of the minority shareholders. A higher anti-self-dealing index indicates a stronger protection for the minority shareholders. As a result, the agency costs between the minority shareholders and the controlling shareholders can be reduced in a country with a high anti-self-dealing index.

We estimate the new model using anti-self-dealing index by a firm fixed effects model. The results are reported in Table 5. The stock liquidity variables are Amihud and quoted spread in columns 1 and 2, respectively. Our results in column 1 confirm our previous finding. The coefficient on the interaction term between Amihud and anti-self-dealing index is positive and significant at the 5 percent level. However, in column 2, although the coefficient on the interaction term between quoted spread and anti-self-dealing index is positive, it is insignificant.

Table 5. Regressions of firm leverage on stock liquidity and anti-self-dealing index

\begin{tabular}{lll}
\hline & \multicolumn{2}{l}{ Dependent variable: LEVERAGE } \\
\cline { 2 - 3 } VARIABLES & $(1)$ & $(2)$ \\
\hline & & \\
AMIHUD & $0.028^{* * *}$ & \\
& $(0.006)$ \\
AMIHUD*ANTI_SELF_DEALING & $0.018^{* *}$ & \\
QUOTED_SPREAD & $(0.009)$ & 0.081 \\
& & $(0.092)$ \\
QUOTED_SPREAD*ANTI_SELF_DEALING & & 0.228
\end{tabular}

(control variables included)

$\begin{array}{lll}\text { Observations } & 16,990 & 17,098 \\ \text { Industry fixed effects } & \text { No } & \text { No } \\ \text { Year fixed effects } & \text { Yes } & \text { Yes } \\ \text { R-squared } & 0.136 & 0.104 \\ * *, \text { and } * \text { indicate statistical significance at the } 1 \%, 5 \%, \text { and } 10 \% \text { level, respectively. }\end{array}$

In the final robustness test, we employ an exogenous event that decreased the creditor rights index of Germany to investigate the impact of creditor rights on the relationship between stock liquidity and firm leverage. Germany experienced a change in creditor rights in 2012. Before 2012, German bankruptcy code could require the incumbent management to be dismissed immediately from the company upon a bankruptcy filing. However, from 2012, the German bankruptcy code allows management to keep their job and manage the company after the bankruptcy filing. Consequently, the creditor rights index of Germany is reduced by one point in 2012. In other words, the creditor rights index of Germany after the reform is reduced from 3 to 2, which is equal to the creditor rights index of Italy. As a result, in this robustness test, our subsample only includes German and Italian firms and we will consider German firms as treated firms and Italian firms as control firms. We then run the following equation: 
LEVERAGE $_{\mathrm{it}}=\alpha_{0}+\beta_{1}$ STOCK_LIQUIDITY $_{\mathrm{it}}+\beta_{2}$ TREATED $_{\mathrm{i}}+\beta_{3}$ STOCK_LIQUIDITY $_{\mathrm{it}} *$ TREATED $_{\mathrm{i}}+$

$\beta_{4}$ TREATED $_{\mathrm{i}} *$ POST $_{\mathrm{t}}+\beta_{5}$ STOCK_LIQUIDITY $_{\mathrm{it}} *$ TREATED $_{\mathrm{i}} * \mathrm{POST}_{\mathrm{t}}+\gamma$ CONTROL $_{\mathrm{it}}+\varepsilon_{\mathrm{it}}$

where $\mathrm{i}$ indexes firm $\mathrm{i}$ and $\mathrm{t}$ indexes time $\mathrm{t}$. The dependent variable of Equation 4 is the firm leverage (LEVERAGE). STOCK_LIQUIDITY is measured by AMIHUD or QUOTED_SPREAD. TREATED is a dummy variable, taking the value of one if firms are German firms and zero if firms are Italian firms. POST is a dummy variable that equals one for the year from 2012 to 2018, and zero otherwise. We do not include the dummy variable POST in Equation 4 because we include the year dummy variables in the equation. The set of control variables in Equation 4 is similar to one in Equation 3. Similar to the standard errors in Equation 3, the standard errors in Equation 4 are also adjusted to heteroskedasticity and clustered at the firm level.

We report the estimation results from Equation 4 in Table 6. We employ a pooled ordinary least squares model and a firm fixed effects model in columns 1-2 and 3-4, respectively. The results show that the stock liquidity variables are positive and significant in 3 out of 4 columns, which is consistent with our previous finding. In this analysis, we focus on the interaction term between three variables that are STOCK_LIQUIDITY, TREATED, and POST. In columns 1 and 4, the coefficients estimated on this interaction term are negative and significant. This suggests that for German firms, the negative impact of stock liquidity on firm leverage is attenuated by the German creditor rights reform. Given that the German creditor rights reform reduced the creditor rights index, this result implies that if the creditor rights index increases, the negative impact of stock liquidity on firm leverage can be strengthened. In columns 2 and 3, although the coefficients on the interaction term are negative, they are insignificant. Overall, our robustness results are consistent with our previous findings.

Table 6. Regressions of firm leverage on stock liquidity and creditor rights reform

\begin{tabular}{|c|c|c|c|c|}
\hline \multirow[b]{3}{*}{ VARIABLES } & \multicolumn{4}{|c|}{ Dependent variable: LEVERAGE } \\
\hline & \multicolumn{2}{|c|}{ POOLED OLS MODEL } & \multicolumn{2}{|c|}{ FIXED EFFECTS MODEL } \\
\hline & $(1)$ & $(2)$ & (3) & $(4)$ \\
\hline AMIHUD & $\begin{array}{l}0.038 * * * \\
(0.008)\end{array}$ & & $\begin{array}{l}0.027 * * * \\
(0.009)\end{array}$ & \\
\hline QUOTED_SPREAD & & $\begin{array}{l}1.180 * \\
(0.693)\end{array}$ & & $\begin{array}{l}0.052 \\
(0.464)\end{array}$ \\
\hline TREATED & $\begin{array}{l}-0.261 * * * \\
(0.031)\end{array}$ & $\begin{array}{l}-0.151 * * * \\
(0.027)\end{array}$ & & \\
\hline AMIHUD*TREATED & $\begin{array}{l}0.012 \\
(0.009)\end{array}$ & & $\begin{array}{l}0.010 \\
(0.010)\end{array}$ & \\
\hline AMIHUD*POST & $\begin{array}{l}0.018^{* * * *} \\
(0.006)\end{array}$ & & $\begin{array}{l}0.013 * * \\
(0.005)\end{array}$ & \\
\hline QUOTED_SPREAD*TREATED & & $\begin{array}{l}-0.643 \\
(0.707)\end{array}$ & & $\begin{array}{l}0.463 \\
(0.529)\end{array}$ \\
\hline QUOTED_SPREAD*POST & & $\begin{array}{l}1.108 * \\
(0.635)\end{array}$ & & $\begin{array}{l}1.474 * * * \\
(0.423)\end{array}$ \\
\hline TREATED*POST & $\begin{array}{l}0.020 \\
(0.022)\end{array}$ & $\begin{array}{l}-0.001 \\
(0.023)\end{array}$ & $\begin{array}{l}0.001 \\
(0.021)\end{array}$ & $\begin{array}{l}0.017 \\
(0.019)\end{array}$ \\
\hline AMIHUD*TREATED*POST & $\begin{array}{l}-0.012 * \\
(0.007)\end{array}$ & & $\begin{array}{l}-0.008 \\
(0.007)\end{array}$ & \\
\hline QUOTED*TREATED*POST & & $\begin{array}{l}-0.818 \\
(0.659) \\
\quad(\text { contro }\end{array}$ & es included) & $\begin{array}{l}-1.469 * * * \\
(0.452)\end{array}$ \\
\hline Observations & 5,314 & 5,330 & 5,314 & 5,330 \\
\hline Industry fixed effects & Yes & Yes & No & No \\
\hline Year fixed effects & Yes & Yes & Yes & Yes \\
\hline R-squared & 0.429 & 0.381 & 0.170 & 0.132 \\
\hline
\end{tabular}

Note: $* * *, * *$, and $*$ indicate statistical significance at the $1 \%, 5 \%$, and $10 \%$ level, respectively. 


\section{Conclusion}

The aim of this paper is to investigate how investor protection affects the relationship between stock liquidity and firm leverage. Our sample consists of listed non-financial companies in four countries that are the UK, France, Germany, and Italy over the period from 2009 to 2018. Using a firm fixed effects model, our results confirm the negative impact of stock liquidity on the firm leverage. In addition, we find that this negative impact of stock liquidity is stronger in countries with strong investor protection than in countries with weak investor protection. Our results are robust when we use a random effects model or when we use an alternative measure of investor protection. Moreover, we find that an exogenous event that reduced the investor protection, measured by creditor rights index, can dampen the negative impact of stock liquidity on firm leverage.

Overall, our paper suggests that the impact of stock liquidity on firm leverage in particular and on other firm characteristics in general may depend on the degree of investor protection. A limitation of this study is that we assume that the impact of investor protection on the relationship between stock liquidity and capital structure is linear. However, the magnitude of this impact can be nonlinear and dependent on the level of investor protection. As a result, future research can pay attention to the nonlinear impact of investor protection on the relationship between stock liquidity and capital structure. Moreover, our paper suggests that future research on how stock liquidity affects firm characteristics, such as firms' default risk, should pay attention to the factors related to the level of investor protection.

\section{References}

Acedo-Ramirez, M. A., \& Ruiz-Cabestre, F. J. (2014). Determinants of capital structure: United Kingdom versus Continental European countries. Journal of International Financial Management \& Accounting, 25(3), 237-270. https://doi.org/10.1111/jifm.12020

Acharya, V. V., \& Pedersen, L. H. (2005). Asset pricing with liquidity risk. Journal of Financial Economics, 77(2), 375-410. https://doi.org/10.1016/j.jfineco.2004.06.007

Acharya, V. V., Amihud, Y., \& Litov, L. (2011). Creditor rights and corporate risk-taking. Journal of Financial Economics, 102(1), 150-166. https://doi.org/10.1016/j.jfineco.2011.04.001

Amihud, Y., \& Mendelson, H. (1986). Asset pricing and the bid-ask spread. Journal of Financial Economics, 17(2), 223-249.

Amihud, Y. (2002). Illiquidity and stock returns: cross-section and time-series effects. Journal of Financial Markets, 5(1), 31-56. https://doi.org/10.1016/S1386-4181(01)00024-6

Brennan, M. J., \& Subrahmanam, A. (1996). Market microstructure and asset pricing: On the compensation for illiquidity in stock returns. Journal of Financial Economics, 41(3), 441-464. https://doi.org/10.1016/0304-405X(95)00870-K

Brennan, M. J., Chordia, T., \& Subrahmanyam, A. (1998). Alternative factor specifications, security characteristics, and the cross-section of expected stock returns. Journal of Financial Economics, 49(3), 345-373. https://doi.org/10.1016/S0304-405X(98)00028-2

Brockman, P., \& Chung, D. Y. (2003). Investor protection and firm liquidity. The Journal of Finance, 58(2), 921-937. https://doi.org/10.1111/1540-6261.00551

Canipek, A., Kind, A. H., \& Wende, S. (2018). The effect of creditor rights on capital structure, investment, and risk: Evidence from a natural experiment. SSRN. Retrieved from https://papers.ssrn.com/sol3/papers.cfm?abstract_id=3121980

Charoenwong, C., Chong, B. S., \& Yang, Y. C. (2014). Asset liquidity and stock liquidity: International evidence. Journal of Business Finance \& Accounting, 41(3-4), 435-468. https://doi.org/10.1111/jbfa.12052

Cho, S. S., El Ghoul, S., Guedhami, O., \& Suh, J. (2014). Creditor rights and capital structure: Evidence from international data. Journal of Corporate Finance, 25, 4-60. https://doi.org/10.1016/j.jcorpfin.2013.10.007

Chordia, T., Subrahmanyam, A., \& Anshuman, V. (2001). Trading activity and expected stock returns. Journal of Financial Economics, 59(1), 3-32. https://doi.org/10.1016/S0304-405X(00)00080-5

Chung, H. (2006). Investor protection and the liquidity of cross-listed securities: Evidence from the ADR market. Journal of Banking and Finance, 30(5), 1485-1505. https://doi.org/10.1016/j.jbankfin.2005.03.021

Dang, T. L., Nguyen, T. H., Tran, N. T. A., \& Vo, T. T. A. (2018). Institutional Ownership and Stock Liquidity: International Evidence. Asia-Pacific Journal of Financial Studies, 47(1), 21-53. https://doi.org/10.1111/ajfs.12202

Djankov, S., La Porta, R., Lopez-de-Silanes, F., \& Shleifer, A. (2008). The law and economics of self-dealing. 
Journal of Financial Economics, 88(3), 430-465. https://doi.org/10.1016/j.jfineco.2007.02.007

Djankov, S., McLiesh, C., \& Shleifer, A. (2007). Private credit in 129 countries. Journal of Financial Economics, 84(2), 299-329. https://doi.org/10.1016/j.jfineco.2006.03.004

Frieder, L., \& Martell, R. (2006). On capital structure and the liquidity of a firm stock. Working Paper. Retrieved from https://papers.ssrn.com/sol3/papers.cfm?abstract_id=880421

Huang, T., Wu, F., Yu, J., \& Zhang, B. (2020). Investor protection and the value impact of stock liquidity. Journal of International Business Studies, 51(1), pp.72-94.

Jensen, M. C., \& Meckling, W. H. (1976). Theory of the firm: Managerial behavior, agency costs and ownership structure. Journal of Financial Economics, 3(4), 305-360.

Jensen, M. C. (1986). Agency costs of free cash flow, corporate finance, and takeovers. American Economic Reiview, 76(2), 323-329.

Lang, M., Lins, K. V., \& Maffett, M. (2012). Transparency, liquidity, and valuation: International evidence on when transparency matters most. Journal of Accounting Research, 50(3), 729-774. https://doi.org/10.1111/j.1475-679X.2012.00442.x

Lipson, M. L., \& Mortal, S. (2009). Liquidity and capital structure. Journal of Financial Markets, 12(4), 611-644. https://doi.org/10.1016/j.finmar.2009.04.002

Marshall, B. R., \& Young, M. (2003). Liquidity and stock returns in pure order-driven markets: Evidence from the Australian stock market. International Review of Financial Analysis, 12(2), 173-188. https://doi.org/10.1016/S1057-5219(03)00006-1

Martinez, M. A., Nieto, B., Rubio, G., \& Tapia, M. (2005). Asset pricing and systematic liquidity risk: An empirical investigation of the Spanish stock market. International Review of Economics and Finance, 14(1), 81-103. https://doi.org/10.1016/j.iref.2003.12.001

Modigliani, F., \& Miller, M. H. (1958). The cost of capital, corporate finance and the theory of investment. American Economic Review, 48(3), 261-297.

Myers, S. C., \& Majluf, N. S. (1984). Corporate financing and investment decisions when firms have information that investors do not have. Journal of Financial Economics, 13(2), 187-221.

Nadarajah, S., Ali, S., Liu, B., \& Huang, A. (2018). Stock liquidity, corporate governance and leverage: New panel evidence. Pacific-Basin Finance Journal, 50, 216-234. https://doi.org/10.1016/j.pacfin.2016.11.004

Pastor, L., \& Stambaugh, R. (2003). Liquidity risk and expected stock returns. Journal of Political Economy, 111(3), $642-685$.

Rajan, R. G., \& Zingales, L. (1995). What do we know about capital structure? Some evidence from international data. The Journal of Finance, 50(5), 1421-1460. https://doi.org/10.1111/j.1540-6261.1995.tb05184.x

Stoll, H. R., \& Whaley, R. E. (1983). Transaction costs and the small firm effect. Journal of Financial Economics, 12(1), 57-79. https://doi.org/10.1016/0304-405X(83)90027-2

Udomsirikuk, P., Jumreornvong, S., \& Jiraporn, P. (2011). Liquidity and capital structure: The case of Thailand. Journal of Multinational Financial Management, 21(2), 106-117. https://doi.org/10.1016/j.mulfin.2010.12.008

Vig, V. (2013). Access to collateral and corporate debt structure: Evidence from a natural experiment. Journal of Finance, 68(3), 881-928. https://doi.org/10.1111/jofi.12020

Wanzenried, G. (2006). Capital structure dynamics in the UK and continental Europe. The European Journal of Finance, 12(8), 693-716. https://doi.org/10.1080/13518470500460178

\section{Notes}

Note $1.55 \%=[0.004 *(5-2) / 0.022] * 100 \%$, where 0.004 is the coefficient on the interaction term between AMIHUD and ANTI_DIRECTOR_INDEX and 0.022 is the coefficent on AMIHUD. 5 and 2 are the maximum and minimum value of ANTI_DIRECTOR_INDEX in our sample, respectively.

Note $2.175 \%=[0.052 *(4-0) / 0.121] * 100 \%$, where 0.053 is the coefficient on the interaction term between QUOTED_SPREAD and CREDITOR_RIGHTS_INDEX and 0.121 is the coefficient on QUOTED_SPREAD.

Note 3. See Canipek et al. (2018) for a detailed discussion about this event.

Note 4 . We include industry dummy variables in the pooled ordinary least squares model. 